\title{
Determining Factors of the Level of Disclosure of Information on Business Combinations with the Entry into Force of the Accounting Standard CPC 15
}

\author{
Wilson Kazumi Nakayama \\ Master of Arts, Department of Accounting and Actuary, School of Economics, Business, and Accounting, University of São Paulo \\ Email:wknakayama@usp.br \\ Bruno Meirelles Salotti \\ Ph.D Professor, Department of Accounting and Actuary, School of Economics, Business, and Accounting, University of São Paulo \\ Email: brunofea@usp.br \\ Received on 05.11.2013-Desk acceptance on 05.23.2013-4 $4^{\text {th }}$ version approved on 08.21.2014
}

\begin{abstract}
This paper aimed to investigate information disclosure on business combination transactions that took place in Brazil in 2010, when the Accounting Standard CPC 15 entered into force, and evaluate which were the determining factors of the level of disclosure of information related to it. To evaluate the disclosure level, a disclosure index of business combinations (INDCOMB) was prepared, having the disclosure index developed by Shalev (2009) as a basis. We evaluated, in the light of the literature on disclosure and business combinations, whether the following factors influenced on the disclosure level: acquiring company size, recognized percentage of overprice for expected future profitability in relation to the transaction value, dispersion of capital of the acquiring company, audit firm size, and participation of the acquiring company in American Depositary Receipts (ADRs) programs. The control variables used were listing of the acquiring company in the various segments of BM\&FBOVESPA, operation sector, origin (state, private company with national capital or private company with foreign capital), and relative acquired company size in relation to the acquiring company. We analyzed business combination transactions that took place in 2010, reported by 40 open capital companies involved in 76 transactions. We conclude that the audit firm size and the relative acquired company size were factors that influenced on the level of disclosure of information regarding business combinations in 2010. The other factors showed no conclusive results.
\end{abstract}

Keywords: Accounting in business associations, Financial statement, Accounting information. 


\section{INTRODUCTION}

Business combination is a transaction where a company acquires control over one or more businesses, regardless of the legal form of the transaction, which may be by means of merger or acquisition of control. It arouses great interest in business circles, because, in addition to the large figures involved, there is an impact on decisions taken by customers, suppliers, and employees associated with these companies. It also raises expectations in the stock market and interest in the academy. In order to think of the magnitude of this kind of transaction, the sale of control over State enterprises earned the Brazilian government the figure of US\$ 105.298 billion, out of which US\$ 78,614 billion only during the Fernando Henrique Cardoso administration.

There is not, yet, a firmly established theory supporting the motivations for the occurrence of business combination. However, there are a number of explanations for the occurrence of these transactions, especially those derived from the Theory of the Firm (Camargos \& Coutinho, 2008), which has in its theoretical framework a logical explanation for the emergence of the firm, its evolution, its growth, and, from this growth perspective, business combination activities are shaped. In the early development stage of the firm, the businessman had full power to decide on business issues. The businessman was both the business owner and administrator. As the company grew, manager-owners started playing a wider range of activities, they were forced to share or even delegate powers so that a professional administrator with more specialized knowledge and managerial ability, could take management positions and make decisions. Besides the administrative complexity that required hiring professional administrators to control the firm, financial constraints due to growing demands have forced companies to go public, dividing their property among a large number of shareholders. This resulted in the separation of company ownership and control.

As a consequence of the separation of ownership and control, conflicts between owners (the firm's shareholders) and professional administrators (those who assumed control) emerged, since both seek to maximize their own interests, which do not always coincide. When the owner-shareholders invest their money in a firm, they are at risk of being expropriated by professional administrators, such as, for instance, when the latter provide themselves with excessive privileges, receive excessive compensation, or make investments or operational decisions that can cause damage to the owners' interests ( $\mathrm{He}$ aly \& Palepu, 2001). Due to the fact that owners are not directly involved in administration, and this function is performed by professional administrators, it is reasonable to suppose that the latter have more information on the firm than its owners. This information asymmetry situation can lead to a collapse of the capital market due to adverse selection. Healy and Palepu (2001) exempli- fied the situation that may occur in the economy considering half of the business ideas as "good" and the other half as "bad". Investors and entrepreneurs act rationally and evaluate an investment having the information they hold as a basis. If investors cannot distinguish between "good" and "bad" business ideas, then, entrepreneurs with "bad" business ideas might argue that their business ideas are "good". Therefore, investors might evaluate investments at a medium level. As a result, if the information asymmetry problem is not solved, the capital market may underestimate the value of good ideas and overestimate the value of some bad ideas. To tackle such a problem, Healy and Palepu (2001) point out some solutions. The first could be optimizing contracts between entrepreneurs and investors, creating incentives for a full disclosure of private information, thus mitigating the issue of investment measurement errors. Another might be regulation, which could require a full disclosure of private information from professional administrators. And, also, a third way might be getting information from intermediaries, such as market analysts and rating agencies, which seek to unravel the information held by administrators.

In Brazil, the disclosure of information on incorporation, merger, or demerger is required by Instruction 319, from the Brazilian Securities Commission (CVM), enacted on December 1999. Alternatively, Instruction CVM 358, enacted in 2002, provides for the disclosure of information on any relevant act or fact concerning open capital companies, among which stands out the transfer of control. It also establishes the obligation to inform the names of the acquiring and acquired companies, a brief summary of the acquiring company's qualification, its business sectors and its activities. It also requires the disclosure of price and other conditions regarding the deal, such as the acquisition purpose and the expected effects on the acquiring company's businesses. It was, however, with the entry into force of the Accounting Standard 15, from the Brazilian Accounting Pronouncements Committee (CPC), which established a robust set of information subject to compulsory disclosure on the part of open capital companies involved in business combination transactions.

Information disclosure plays a significant role by reducing the information asymmetry between the company and its shareholders, but there are costs to the company associated with the production and dissemination of such information. A component of this expense is ownership cost, related to the company's expenditure due to strategic information disclosure. Such information may be used by competitors, for instance, at the company's expense. Thus, companies assess the costs and benefits of information disclosure, even those related to mandatory disclosure information (Dye, 2001; Robinson, Xue, \& Yu, 2011; Verrecchia, 2001). 
Although CVM requires the disclosure of information on transactions regarding merger and demerger since Instruction CVM 319 was enacted in 1999, and despite the requirement of information disclosure concerning the transfer of control since Instruction CVM 358 was enacted, in 2002, there is no data confirming the existence of an index demonstrating the information disclosure level required from then on. Thus, this study aims to evaluate, by constructing a disclosure index (INDCOMB), based on the information required by the Accounting Standard CPC 15 , the level of disclosure of information related to business combinations that took place in 2010. By using the index INDCOMB, this study seeks to answer the following research question: "Since the entry into force of the Accounting Standard CPC 15 - Business Combinations -, containing compulsory rules for disclosure of information on business combinations, which factors do influence the information disclosure level in transactions?".
This study aims to find evidence of the factors influencing on the company's decision to disclose a greater or lesser amount of information on business combination transactions.

It is hoped that this study can contribute so that users, regulators, and preparers of financial statements apprehend the mechanisms associated with the level of disclosure of information on these significant business combinations.

In addition to this brief introduction, which sought to contextualize the problem, this paper is divided into the following sections: section 2 reviews the surveys relating the disclosure level to the company's characteristics, which are used to ground the research hypotheses. Section 3 describes the methodology employed, the empirical model, the way how the disclosure index INDCOMB was constructed, and the information sources. Section 4 presents the results and, finally, our conclusions are drawn.

\section{THEORETICAL FRAMEWORK AND CONSTRUCTION OF HYPOTHESES}

\subsection{Disclosure and business combination}

Merger and acquisition transactions constitute the fastest way to grow a company, enter into markets where it is not operating, yet, fight against unwanted acquisitions, take advantage of investment opportunities or, even, to lead some participants in these processes to profit at the expense of others (Camargos \& Barbosa, 2003).

As it is an transaction that significantly affects the interests of shareholders, the disclosure of information related to these transactions plays an important role in reducing information asymmetry between the company's administration and its shareholders.

According to Shalev (2009), the administrators tend to disclose more information on acquisitions that are expected to create value for the acquiring company (good news) and disclose less information on acquisitions that are less likely to be profitable (bad news).

According to Healy and Palepu (2001), the problem of information asymmetry causes the phenomenon of adverse selection, i.e. as it is not possible to distinguish good investments from bad investments, the market evaluates investments by an average level, hindering the development of this market.

To tackle this problem, Healy and Palepu (2001) point out two solutions. The first might be optimizing contracts between entrepreneurs and investors, leading them to promote full disclosure of private information, thus mitigating the issue of error in investment evaluation. The second is regulation, which might require full disclosure of private information from professional administrators.

On the other hand, the company may judge that the disclosure of information related to business combination may entail high costs to owners, something which could lead them to restrict or even reduce the disclosure level. In such a situation, the disclosure of information on business transactions should be compulsory.

According to Dye (2001), there is not yet an established theory on mandatory disclosure, in part because few analytical investigations were conducted to address accounting standards in the previous two decades. Schipper (2007) confirms this, and also argues that theorists cannot agree on what should be optimized in terms of disclosure requirements. Furthermore, the theoretical models also face difficulties in distinguishing between items recognized in the financial statements and those disclosed only in the notes.

In economic terms, the underlying idea to disclosure regulation is that companies do not voluntarily open the information when the cost is greater than the effects produced by it on firm value (Verrecchia, 2001). Thus, the regulation could make compulsory the disclosure of information that would not be disclosed on a voluntary basis, although it is noticed that mandatory disclosure does not necessarily indicate that all information is disclosed, as documented by other surveys indicating a low level of disclosure of mandatory information (Ayers, Schwab, \& Utke, no prelo; Devalle \& Rizzato, 2012).

Despite this fact, among the reasons for the existence of regulation, there is the idea that accounting information may be seen as a public good (Leftwich, 1980). A second explanation for disclosure regulation is the concern of regulators with unsophisticated investors (Leftwich, 1980). Ensuring minimum compulsory disclosure, regulation seeks to reduce the gap of information between informed and uninformed investors. Regulation may be a way to reduce the possibility of 
manipulation of accounting figures, but it might also be biased. According to Martins and Iudicibus (2011, p. 72):

[...] regardless of how good the regulators' purposes are, there are always political aspects involved favoring some groups and damaging others.

It is known that, on the other hand, absolute Accounting neutrality is unattainable, because choices are always made.

\subsection{Disclosure and the company's characteristics}

According to Ahmed and Courtis (1999), the typical methodology employed in surveys relating the disclosure level to the company's characteristics is that involving the construction of an index and the ratio between the amount of informational items disclosed and the selected corporate characteristics. In this study, we sought to determine whether the acquiring company's characteristics (size, control structure, and listing on foreign stock exchanges), as well as the percentage of recognition of goodwill in relation to the value of transferred consideration and the audit firm size influenced the level of disclosure on the business combination transaction.

In the meta-analysis of surveys on disclosure carried out by Ahmed and Courtis (1999), the most frequent variable when relating the disclosure level to the company's characteristics was its size. According to Ahmed and Courtis (1999), several studies (Singhvi \& Desai, 1971; Cooke, 1989) found out a positive relation between disclosure and firm size. According to the authors, the results suggest that larger firms had better disclosure level. There are several hypotheses that explain the positive relation between disclosure and size, among which those raised by Singhvi and Desai (1971), arguing that the larger the firm size, measured by total assets, the higher the disclosure, due to the fact that the cost to generate information is relatively lower for larger companies. In addition, Wallace and Naser (1995) also argue that larger companies typically attract more customers, suppliers, and analysts, and, therefore, a greater demand for more information on their activities. In a survey with a sample of 130 companies from Hong Kong within the period from 1988 to 1992, these authors also found a positive relation between size and the level of disclosure of mandatory information.

However, Street and Bryant (2000), Glaum and Street (2003), and Street and Gray (2002) found no evidence that firm size has a positive relation to the level of compliance with the requirements of international standards.

In Brazil, Murcia and Santos (2009) analyzed the voluntary information disclosure contained in the Brazilian Standardized Financial Statements (DFP) for the fiscal year 2007 of the 100 largest Brazilian non-financial open capital companies. These authors found that company size is positively related to the information disclosure level and the results corroborate the idea that larger fir$\mathrm{ms}$, due to their greater visibility in society, have a wider group of interested people following up its performance. Thus, being more transparent, they increase their reputation with this audience and suffer less pressure.

Based on the evidence found in the surveys cited, it is possible to formulate the following hypothesis:

$\mathrm{H1}$ : The disclosure level of business combinations has a positive correlation to the acquiring company size.

Accounting considers the acquired goodwill as waste, it is addressed as the difference between the value attributed to business and the net value of assets and liabilities measured at fair value. Therefore, goodwill includes non-identifiable intangible assets, future profitability, and, occasionally, overpricing. If a significant portion of the value attributed to business is recognized as goodwill, it may be a sign that the acquiring company paid more than the acquired company is worth, according to market assessment, and it may not be interesting to have a high level of disclosure of information on the transaction. Shalev (2007) identified two phenomena in business combination that might encourage administrators to use the materiality criterion to reduce the level of disclosure of information on the transaction, namely, transaction overprice and distorted allocation in transaction value, overestimating the value of recognized goodwill. Overprice may be motivated by the entry into a new market where the acquiring company has no operations or as a way to increase its market share or also by miscalculation. But it may also be due to overconfidence or even arrogance on the part of the acquiring company's administrator. It is worth emphasizing, therefore, that the value the acquiring company assigns to business may be different than the average market assessment. This may take place due to various reasons and only the acquiring company knows them. Without ignoring the possibility that the deal has some managerial motivation, the company could enter into business only if advantages are expected in the best sense of optimizing its wealth. According to Shalev (2007), it is possible that overpricing leads to an exaggerated recognition of goodwill value. The intentional and distorted recognition of goodwill value, according to Shalev (2007), is the belief that investors have in the functional attachment of profit. Thus, the systematic amortization of goodwill is no longer allowed by the U.S. accounting standards, the transaction could result in an increased income reported by the combination and it might be an incentive for managers to recognize a distorted goodwill value. Shalev (2007) found that disclosure is lower as the portion of the transaction amount recognized as goodwill in relation to the value of the transaction is higher. According to Shalev (2007), when the acquirer pays a lot more than the acquired company is worth or when the goodwill value is "exaggerated" in relation to the transaction value, the acquirer tends to disclose less information on the business combination. The goodwill, besides being no longer systematically amortized in accounting terms may be deducted from income tax in Brazil, under 
certain conditions ${ }^{1}$, something which may encourage administrators to recognize a substantial portion of the transaction value as goodwill. Taking into account, therefore, that it would not be interesting for managers to reveal overpricing or distorted recognition of the goodwill value, considered as "bad news", the hypothesis posed is:

H2: The disclosure level of a business combination has a negative correlation to the ratio between the recognized goodwill and the transferred consideration value.

According to the agency theory, the separation of ownership and control has led to the emergence of agency conflict. This is also derived from the separation of firm ownership and control and due to the fact that agents are engaged in its operation, they have more information than investors, resulting in information asymmetry among stakeholders. Shleiffer and Vishny (1986) found that the interests of the controlling shareholders do not necessarily coincide with those of other investors in the company. The presence of big shareholders may end up generating conflict between controlling and non-controlling shareholders, there is a possibility that the latter are expropriated by the former. This possibility may be due, for instance, to the inefficiency resulting from the pursuit of personal objectives that do not optimize the company's value. The expropriation of non-controlling shareholders by the controlling shareholders may take place, according to Lanzana (2004), by the appointment of individuals connected to the controller to manage the company, the valuation of investments based on the controller's personal interest, among others reasons. As the fact that the controlling shareholder has privileged access to information would not require information disclosure (Leuz \& Verrecchia, 2000), it is expected that companies with more dispersed ownership capital disclose more information than those controlled by major shareholders (Raffournier, 1995; Wallace \& Naser, 1995). The hypothesis formulated having theory as a basis is:

H3: The disclosure level of a business combination has a positive correlation to the dispersion of capital.

Audit services are demanded as monitoring tools against the potential conflict of interest between company owners and administrators, as well as between the various classes of shareholders, according to Deangelo (1981). Audited financial statements could be the cheapest solution to agency conflicts. Audit quality is related to auditor's independence from its client. According to Deangelo (1981), the higher the audit firm in relation to the current number of customers and the smaller the firm in relation to its revenue, less incentive the auditor might have to act on a timely basis and the greater might be the perceived audit quality. Large audit firms, the so-called "Big Four" (KPMG, PricewaterhouseCoopers, Deloitte Touche Tohmatsu, and Ernest \& Young), tend not to associate with companies having low disclosure level (Ahmad,
Hassan, \& Mohammad, 2003). Dumontier and Raffournier (1998) also argue that auditors from the largest companies have an interest of their own in seeing clients in accordance with complex accounting standards, because they can enhance their reputation and take competitive advantage in the application of international accounting standards. Murcia and Santos (2009), in a survey on the determinants of voluntary disclosure level in the financial statements for the years 2006, 2007, and 2008 of Brazilian open capital companies, found evidence that companies audited by the "Big Four" had higher disclosure of economic information. On the other hand, Wallace and Naser (1995) found no relation between the mandatory disclosure level and this variable in their research with 130 companies from Hong Kong. It is assumed that the largest audit firms, by having international experience in the use of these rules on disclosure of business combination transactions, are more prepared than their local counterparts to certify disclosure. Thus, the following research hypothesis is formulated:

H4: The disclosure level of a business combination has a positive correlation to the audit firm size.

An alternative to raise funds for Brazilian open capital companies is resorting to international markets. By means of the American Depositary Receipts (ADRs), Brazilian companies have the possibility to trade their securities in the United States, the largest capital market in the world. According to Lanzana (2004), the possibility that Brazilian companies issue ADRs, or debt securities in the U.S. market, has required a greater information disclosure level from these companies than that required by the Brazilian law. According to Leuz and Wysocki (2008), the U.S. securities legislation protects the rights of foreigner investors more than in their own countries of origin, and these rights are more strictly required both by the Securities and Exchange Commission (SEC) and the U.S. courts on security litigation. When listing their securities on U.S. stock exchanges, foreign companies are subject to their laws and their respective enforcement. The disclosure policy of a company tends to be influenced by the disclosure policy of the capital market where its securities are traded, according to Archambault and Archambault (2003). Murcia and Santos (2009) analyzed the determining factors of the voluntary disclosure level of the 100 largest non-financial Brazilian open capital companies traded on the basis of financial statement analysis for the fiscal year 2007. The authors found a positive correlation between the disclosure and participation level of the company in an ADR program levels II and III. Based on theory and evidence of the cited studies, it is possible to formulate the following hypothesis:

H5: The disclosure level of a business combination transaction has a positive correlation to the company's participation in ADR programs.

The amortization of goodwill for future profitability has no effects on the calculation of income tax, as provided for by Article 25 of Decree-Law 1,598. However, Article 7 of Law 9,532, enacted on December 10, 1997, provides for the amortization of goodwill for future profitability, impacting, therefore, on the calculation of income tax if a company absorbs the assets of another in virtue of merger or demerger, in a situation where it had already acquired stake in goodwill. 


\subsection{Disclosure index}

Financial information disclosure is an important means of communication between the company administration and investors and the other market participants. The demand for disclosure derives from the issue of information asymmetry and agency conflicts between administrators and investors (Healy \& Palepu, 2001). An indirect way to measure disclosure is by constructing an index based on observable variables related to disclosure. Observable aspects may be both objective, having a numerical quantification, and subjective, related to information quality. So, this index shows the disclosure level of a group of companies, which may be used to show the compliance with standards if the items making up the index are required or it can demonstrate the voluntary disclosure level. When the researcher uses a disclosure index his research, he may choose to use an index that already exists or construct his own index. By using already existing disclosure indexes, the researcher has the advantage of making direct comparisons of his research to previous studies (Marston \& Shrives, 1991) and he also has the benefit of saving survey time, but restricts himself to pre-defined items, without having the flexibility to add or remove items as he deems needed in his survey. The current indexes may be the ranking of the Center for International Financial Analysis and Research (CIFAR), the Association for Investiment and Management Report (AIMR), and the transparency indicator of Standard \& Poors. In Brazil, there are the transparency rankings of the Brazilian Association of Open Capital Companies (ABRASCA) and the award of the National Association of Finance Executives (ANEFAC).

With the option to construct an index of his own, the researcher deems more appropriate to choose items suitable to the context of his survey. Then, items making up the index are chosen among those that the researcher considers as related to disclosure. Although they may be subject to criticism and disagreement, like any other research tool in social sciences, disclosure rates have been used since the 1960s by many researchers. The disclosure index provides the answers to researchers' hypotheses in many situations, confirming its usefulness, since a research tool would not be used by providing poor results (Marston \& Shrives, 1991).

The Brazilian literature has many studies addressing information disclosure, such as Costa Jr. (2003), Malacrida and Yamamoto (2006), Salotti and Yamamoto (2008) and Lima (2009). Regarding the disclosure index, we may cite Lopes and Rodrigues (2007), who used a disclosure index based on the information required by the international accounting standards to analyze the determining factors of disclosure for companies listed on the Portuguese stock exchange. Mapurunga, Rocha, Ponte, Coelho and Meneses (2011) used a disclosure index based on CPC 14, which deals with financial instruments, to check the disclosure level of Brazilian companies. Malaquias, Lemes, Carvalho and Tavares (2012) investigated the correlation between the capital cost of Brazilian companies and the level of disclosure of information on financial instruments that these companies report on the form $20 \mathrm{~F}$ and the financial statements prepared and disclosed in accordance with the accounting practices adopted in Brazil.

\subsubsection{Disclosure Index of Business Combination (INDCOMB)}

This study aims to analyze the mandatory disclosure of information on business combination in accordance with CPC 15. The existing rankings and indicators on disclosure in Brazil have a general nature, they do not focus on the disclosure of a specific information type. Although CVM requires disclosure on incorporation, merger, and demerger transactions since Instruction CVM 319 was enacted, in 1996, and despite the requirement of disclosure in the transfer of control since the enactment of Instruction CVM 358 , in 2002, there is no knowledge of an index demonstrating the level of information disclosure specifically regarding these transactions. Thus, we chose to prepare a disclosure index addressing business combination (INDCOMB) transactions, adapted from disclosure index developed by Shalev (2009), which was based on business combination information required by the U.S. accounting standards ${ }^{2}$. When preparing INDCOMB, we used the information required by the Accounting Standard CPC 15.

We chose the content analysis technique to analyze the information contained in the DFPs submitted by companies to CVM. In order to ensure a rather objective and systematic analysis of information and reduce subjectivity, the information required by CPC 15 were classified and grouped according to theme addressed into 10 categories and 65 subcategories: General Information (12) Information on the allocation of purchase price (7), Information on contingent consideration agreement (4), information on contingent liabilities (5), Information on goodwill (13), Information on transactions recognized separately from combination (7), Information on business combination achieved in stages (3), Financial information on the acquired company included in the consolidated statements (4), Information on business combinations whose acquisition date was after the end of the reporting period (3), Information on changes that took place in the acquired assets, and liabilities taken within the reporting period (7).

\section{METHODOLOGICAL ASPECTS}

\subsection{Definition of information categories and subcategories}

In this article, we chose to assign binary values to each information item required, assigning the value " 1 " if the company disclosed the required information (1), or " 0 " if it did not disclose the information (0), as adopted by several surveys on disclosure (see, for instance, Botosan, 1997; Devalle \& Rizzato, 2012; Shalev, 2009; Yeoh, 2005). Although 
there are surveys where values are set according to the specificity degree of each information item (see, for instance, Lanzana, 2004; Wiseman, 1982), it is believed that this way of assigning value establishes a certain subjectivity degree not desirable to the survey.

When the notes had no mention to a certain informational item, it was assumed that the item did not apply to the case. However, if after reading the whole financial statement it was concluded that the item was significant but it was not disclosed, " 0 " is assigned to that informational item. This procedure introduces a subjectivity element, but it was understood that this procedure introduced a smaller bias than simply considering the dichotomous condition "disclosed/did not disclose" information. That was the way of assigning value used by Cooke (1989).

The disclosure index may be understood as the compliance level, because these items are of compulsory disclosure. Just as found by Hodgdon, Tondkar, Harless and Adhikari (2008), even companies that have claimed to adopt the International Financial Reporting Standards (IFRS) in 1999 and 2000 did not do that adequately. In addition, Chatham (2008) analyzed the level of compliance with IFRS by French, Swedish, and Swiss companies which claimed to follow the international accounting standards, reaching insights regarding what might motivate companies to meet or not the requirements of those standards. So, it is understood that the fact that there is a mismatch between what the standard establishes and what is observed by firms is perfectly "natural" at the inception of a new standard.

The index is based on Tsalavoutas, Evans and Smith (2010) and calculated according to the formula:

$$
\mathrm{INDCOMB}=\frac{\sum_{i=1}^{n} d i}{\sum_{j=1}^{m} d j}
$$

Where $d i$ is the total number of items disclosed by the company (which was assigned the value " 1 ") and $d j$ is the total number of items the company should have disclosed.

\subsection{Information sources}

The identification of a business combination transaction may be achieved by referring to the notes to the financial statements published by companies listed on the stock exchange. As this procedure might require a long time, we sought an alternative to obtain the list of business combinations that took place in 2010. Studies and analyses on merger and acquisition transactions conducted by entities such as the National Association of Investment Banks (ANBID) and PricewaterhouseCoopers and event reports from the Bloomberg database constitute sources of information on merger and acquisition transactions occurred in Brazil.

The information available in the ranking of mergers and acquisitions of ANBID was crossed with informa- tion from the Bloomberg database and the reports on mergers and acquisitions from PricewaterhouseCoopers, in order to obtain a list of companies involved in merger and acquisition transactions. In order to achieve confirmation that all business combination transactions had been listed, searches were performed in the documents filed by the companies in CVM the fiscal year 2010, on the documents entitled "Relevant Fact", "Shareholders Meeting", and "Notice to the Market", by means of the system for Submission of Periodical and Occasional Information (IPE), which is a repository of documents that open capital companies are required to file in CVM. The search was performed by checking the period from January 1, 2010, to December 31, 2010. Document categories were those previously reported and the keywords adopted were "acquisition", "combination", "merger", and "reorganization". Transactions not considered as business combination were excluded. In the final list, 40 companies involved in 76 mergers and acquisitions remained. Information regarding the disclosure of business combination transactions were obtained from the financial statements of companies filed in CVM or those published in newspapers or on each company's website. We also analyzed the reports of the independent auditors, in order to check the existence of any reservation or emphasis involving the subject "business combinations" and there was no specific mention to this theme in the 40 companies under analysis.

\subsection{Empirical model}

To test the research hypotheses, we used multiple linear regression, in its cross-sectional type, by means of the ordinary least squares (OLS) method, having as dependent variable the disclosure index INDCOMB and explanatory variables related to the hypotheses described in items 3.4 and 3.5, according to the general model:

$\mathrm{INDCOMB}_{\mathrm{i}}=\alpha+\beta_{1^{*}}$ SIZE $+\beta_{2}{ }^{*}$ GOODWILL $+\beta_{3}{ }^{*}$ DISPERSION $+\beta_{4}{ }^{*} \mathrm{AUDIT}+\beta_{5}{ }^{*} \mathrm{ADR}$ LISTING $+\sum_{j=1}^{k} \mathrm{CV}_{\mathrm{ji}}+\varepsilon_{\mathrm{i}}$

Where $i$ represents the $i_{\text {th }}^{\text {th }}$ company, SIZE, GOODWILL, DISPERSION, AUDIT, and ADR_LISTING are proxies for variables related to the research hypotheses, CV are control variables, and $\varepsilon_{\mathrm{i}}$ represents the term unsystematic error in the model.

Based on the reviewed literature and the research hypotheses, we expect to identify a statistically significant relation between the dependent variable INDCOMB and the explanatory variables in the model that contribute to answer the following questions:

- Are large companies more concerned with the disclosure of information on business combination transactions?

- When companies recognize goodwill as a significant portion of the purchase price, do they tend to disclose less information on the transaction? 
- Do companies with dispersed capital tend to disclose more information on business combination transactions?

- Does audit firm size influence on the decision to disclose more information on business combination transactions?

- Do companies participating in the U.S. stock market exchages represent greater concern with disclosure on business combinations?

\subsection{Operational definition of variables}

- SIZE represents the acquiring company size. In this study, the proxy for firm size was the natural logarithm of total assets in the end of the reporting period.

- GOODWILL is the ratio between the value recognized as goodwill (overprice for expected future profitability) and the value of transferred consideration. The value regarded as transferred consideration was the amount delivered to assume control (which may have been in cash, capital instruments, or assumption of liabilities).

- DISPERSION is the variable to characterize capital dispersion. In this study, the variable DISPERSION was defined as the percentage of shares with voting rights held by non-controlling shareholders. The values were obtained from the reference form filed by the company in CVM.

- AUDIT is the dummy variable indicating whether the audit service was provided by one of the big audit firms, the so-called Big Four (KPMG, PricewaterhouseCoopers, Deloitte Touche Tohmatsu, and Ernest \& Young). This is a dichotomous variable to which the value " 1 " has been assigned if the audit service was provided by one of the "Big Four" or " 0 " if the audit service was provided by other companies.

- ADR_LISTAGEM is the dummy variable indicating whether the acquiring company issues ADRs levels II and III, if it has issued the value " 1 " was assigned and " 0 " if it has not issued. Information was obtained from the website of CVM and the situation took into account in the end of the reporting period, i.e. for being regarded as ADR issuer the company should have its registration approved by CVM until 12/31/2010.

\subsection{Control variables}

Control variables were selected based on previous surveys and the possible influence on the dependent (INDCOMB) and independent (SIZE, GOODWILL, DISPERSION, AUDIT, and ADR_LISTING) disclosure variables. Control variables (which are independent variables) are inserted into the model to remove their effects on the study results. The selected control variables and their proxies are described below.

- Relative_size: Málaga (2007) reports several researches that point out the use of the acquired company's relative size as a control variable in regressions. The results of these studies suggest, according to Málaga (2007), that the acquired company's relative size, among other factors, influenced on the acquirers' short and long term return. However the results were not conclusive. In this study, relative size is defined as the ratio between the transaction value and the acquirer's total assets (obtained from the consolidated financial statements) in the end of the reporting period.

- Listing status (listing): Kent and Stewart (2008) argue that a better corporate governance structure leads to better disclosure levels and they obtained empirical evidence with Australian companies that confirm this relation. Murcia and Santos (2009) found that companies from different sectors in the Brazilian Mercantile and Futures Exchange and the São Paulo Stock Exchange (BM\&FBOVESPA) tend to have higher disclosure level. Companies listed in the New Market of BM\&FBOVESPA indicate that they have the best corporate governance practices and, therefore, should provide fuller financial data and annual reports on internationally accepted standards. We used a dichotomous variable to indicate whether the acquiring company was listed in the various segments of BM\&FBOVESPA (New Market and Level II) up to $12 / 31 / 2010$.

Operation sector (sector): In addition to the accounting regulation issued by CVM some open capital companies are also subject to standards issued by government regulatory agencies, such as the National Electric Energy Agency (ANEEL) and the Central Bank of Brazil (BACEN). Murcia and Santos (2009) found that companies from the electric sector, subject to the standards of ANEEL, have higher disclosure level than the other companies. We used the dummy variable to indicate whether the company acted in sectors subject to the standards issued by ANEEL and BACEN.

- Origin of the acquiring company (origin): According to Lanzana (2004), State companies may be motivated by having higher disclosure level on the market than their private counterparts in view of their "social role". The researcher classified companies into three groups, according to their origin: state-owned, national private, and foreign private company. In this research, we used dummies indicating the origin of the acquiring company under analysis in Lanzana (2004).

\section{RESULTS}

\subsection{Descriptive statistics}

In addition to the disclosure index INDCOMB, calculated having equation (1) as a basis, we calculated the dis- closure index for each information category, obtaining the results shown in Table 1: 
Table 1

Results of the descriptive statistics

\begin{tabular}{|c|c|c|c|c|c|}
\hline Index & Minimum & Maximum & Average & Standard deviation & Coefficient of variation \\
\hline Overall score (INDCOMB) & 0.2857 & 0.8519 & 0.6026 & 0.1675 & 0.2780 \\
\hline General information & 0.5556 & 1 & 0.8538 & 0.1378 & 0.1614 \\
\hline Allocation of the transaction value & 0 & 1 & 0.5167 & 0.3434 & 0.6646 \\
\hline Contingent consideration agreement & 0.25 & 1 & 0.6786 & 0.3134 & 0.4618 \\
\hline Goodwill & 0 & 1 & 0.4402 & 0.2613 & 0.5936 \\
\hline Transactions separate from combination & $\mathrm{N} / \mathrm{A}$ & $\mathrm{N} / \mathrm{A}$ & $\mathrm{N} / \mathrm{A}$ & $\mathrm{N} / \mathrm{A}$ & $\mathrm{N} / \mathrm{A}$ \\
\hline Combination achieved in stages & 0 & 0.6667 & 0.2778 & 0.2509 & 0.9032 \\
\hline Acquired company's financial information & 0 & 1 & 0.3167 & 0.3785 & 1.1951 \\
\hline Combination that occurred after the reporting period & 0 & 1 & 0.7179 & 0.3561 & 0.4960 \\
\hline Changes in recognized assets and liabilities & 0 & 1 & 0.4389 & 0.4064 & 0.9260 \\
\hline
\end{tabular}

$\mathrm{N} / \mathrm{A}$ - not available

Overall score: The average disclosure rate was 0.6026 . We emphasize that this result was obtained through information that "theoretically" might be mandatorily disclosed, indicating that a significant part of the information required by CPC 15 have not been disclosed. However, this result is not a matter of surprise, since it is consistent with other studies that also documented non-disclosure of mandatory information (see, for instance, Ayers et al., no prelo; Devalle \& Rizzato, 2012).

Overall information score: The average rate 0.8538 in this category indicates that companies have disclosed overall information related to transactions in an adequate way, this has been the highest individual score. It is observed that in this information category the disclosure of owner information has not been required, something which may justify its high level.

\section{Score of information on allocation of transaction} value for the assets: The information in this category refer to the book values and fair values of recognized assets acquired and liabilities assumed. The average rate 0.5167 , with a coefficient of variation of 0.6646 indicate low disclosure levels, with very big differences between the information provided by companies.

\section{Score of information on contingent consideration} agreements: Few companies have reported the existence of a contingent consideration agreement. The doubt is whether the small amount of companies reporting the existence of this agreement type is due to the fact that, actually, there are no agreements between buyer and seller or because of the former Brazilian accounting practices, which did not prescribe the disclose of this information.

- Score of information on recognition of contingent liabilities: This is one of the exceptions to CPC 25 Provisions, Contingent Liabilities and Contingent Assets - in recognizing contingent assets and liabilities deriving from business combination. Few companies have recognized the existence of contingent liabilities deriving from combination. The rate 0.5944 , with a coefficient of variation of 0.5607 , indicate low disclosure level and a big difference between the companies that reported information in this category.

Score of information on goodwill: Information on goodwill recognized in a business combination was very poor, as it may be evidenced by the low rate 0.4402 . In addition, there are major differences between information provided by companies, because the coefficient of variation was 0.5936 . It is observed that there is still some conceptual confusion regarding overprice and goodwill at some companies. The most common is naming goodwill as the difference between the value of transferred consideration and the net value of assets and liabilities. Concerning the qualitative factors that make up goodwill, generally companies just declared that the overprice for future expectation was grounded in a report prepared by a specialized company.

Score of information on transaction separate from combination: We did not identify any company that has reported a transaction separate from combination.

\section{Score of information on business combination achie-} ved in stages: Few companies reported that they held prior participation in acquired companies before acquiring control.

Score of financial information of the acquired company: The average rate 0.3167 indicates that companies had few required information. Additionally, there is a big difference between companies; some did not disclose any information and others disclosed all required information.

\section{Score of information on combination of operations} occurring after the reporting period: Only 13 companies reported conducting a business combination transaction after the reporting period. The information is contained in the item named subsequent events and, generally, does not meet the information requirements of CPC 15. The information disclosed was quite succinct.

Score of information on changes in recognized values: Few companies have identified changes in values recognized in the initial accounting. 


\subsection{Results of the empirical model}

Preliminarily, we conducted a survey of the correlation between variables of the model, obtaining the results displayed in Table 2.

Table 2

Correlation matrix

\begin{tabular}{l|r|r|r|r|r|r|r|r|r}
\hline & \multicolumn{1}{|c|}{ indcomb } & \multicolumn{1}{c|}{ assets } & \multicolumn{1}{c|}{ goodwill } & \multicolumn{1}{c|}{ dispersion } & \multicolumn{1}{c|}{ audit } & \multicolumn{1}{c|}{ listing } & \multicolumn{1}{c|}{ adr } & sector & rel_size \\
\hline indcomb & 1.0000 & & & & & & & & \\
\hline assets & 0.0517 & 1.0000 & & & & & & & \\
\hline goodwill & -0.0320 & -0.2240 & 1.0000 & & & & & & \\
\hline dispersion & -0.0250 & -0.1320 & -0.0697 & 1.0000 & & & & & \\
\hline audit & 0.3372 & 0.2200 & 0.3031 & 0.0997 & 1.0000 & & & & \\
\hline listing & 0.0936 & -0.3910 & 0.1554 & 0.5362 & 0.0000 & 1.0000 & & & \\
\hline adr & 0.0633 & 0.7000 & -0.3932 & -0.1813 & 0.1400 & -0.4042 & 1.0000 & & \\
\hline sector & 0.0298 & 0.2597 & -0.1450 & -0.0282 & 0.0949 & -0.0548 & 0.1462 & 1.0000 & \\
\hline rel_size & 0.3344 & -0.2890 & 0.0952 & 0.1895 & -0.0047 & 0.2550 & -0.2121 & 0.2931 & 1.0000 \\
\hline
\end{tabular}

legend:

indcomb $=$ index of business combination INDCOMB

assets $\quad=$ natural logarithm of total assets

goodwill = ratio between recognized goodwill and the value of transferred consideration

dispersion $=$ percentage of common shares held by non-controlling shareholders

audit = dummy indicating that the audit firm is one of the Big Four

listing = dummy indicating that the company is listed on the new Market or on BM\&FBovespa level 2

$\mathrm{adr} \quad=$ dummy indicating that the company issues ADRs

sector = dummy indicating that the company operates in the financial or electric sector

rel_size = ratio between the transaction value and the the acquiring company's total assets

We notice a significant positive correlation between the disclosure index and the independent variables relative size and audit firm, enabling evidence that the acquired company size and the audit firm influence on the disclosure of information on the business combination.

The variable goodwill (percentage of goodwill in relation to the value of transferred consideration) expresses a negative correlation to the disclosure rate of INDCOMB, it seems to indicate that a greater recognition of goodwill in relation to the transaction value leads companies to disclose a lower level of information, in line with what was observed by Shalev (2009).
The correlation between the variable percentage of goodwill in relation to the transaction value and the total assets shows a negative sign, suggesting that smaller companies tend to recognize greater goodwill in the transaction. According to the observation of a negative correlation between the variable indicating participation in ADR programs and the percentage of goodwill identified in relation to the transaction value, companies that list their shares on American stock exchanges recognize lower goodwill in transactions.

We used the statistical software Stata and the results are shown in Table 3.

Table 3

Results of regression

\begin{tabular}{|c|c|c|c|c|c|c|}
\hline & Coef. & Std. Err & $t$ & $P>|t|$ & \multicolumn{2}{|c|}{ [95\% conf. interval] } \\
\hline assets & .0152439 & .0201705 & 0.76 & 0.456 & -.0258942 & .0563819 \\
\hline goodwill & -.1084677 & .0695888 & -1.56 & 0.129 & -.2503951 & .0334597 \\
\hline dispersion & -.1967892 & .1290954 & -1.52 & 0.138 & -.460081 & .0665026 \\
\hline audit & .245981 & .0921305 & 2.67 & 0.012 & .0580797 & .4338824 \\
\hline listing & .0740528 & .0732194 & 1.01 & 0.320 & -.0752791 & .2233848 \\
\hline $\mathrm{adr}$ & -.0331007 & .1049792 & -0.32 & 0.755 & -.2472071 & .1810058 \\
\hline sector & -.1391803 & .1058138 & -1.32 & 0.198 & -.3549889 & .0766283 \\
\hline rel_size & .4922631 & .1800548 & 2.73 & 0.010 & .1250388 & .8594874 \\
\hline _cons & .0865779 & .4391994 & 0.20 & 0.845 & -.8091751 & .9823309 \\
\hline Number of observations & 40 & & & & & \\
\hline F statistics & 1.98 & & & & & \\
\hline$P$ value & 0.0827 & & & & & \\
\hline R squared & 0.3383 & & & & & \\
\hline Adjusted R squared & 0.1675 & & & & & \\
\hline
\end{tabular}


We can notice that the model with all independent variables included has no statistical significance at 95\% confidence level, according to F test, and there are even proble$\mathrm{ms}$ of multicollinearity between some variables, such as, for instance, $a d r$ and assets. However, as the variables audit and relative size have proved to be significant, then, the stepwise procedure was executed to remove from the model statistically non-significant variables and check if they result in a model that demonstrates explanatory power. Thus, executing the procedure, we obtained the results displayed in Table 4.

Table 4

Results regression by using the stepwise procedure

\begin{tabular}{|c|c|c|c|c|c|c|}
\hline & Coef. & Std. Err & $t$ & $P>|t|$ & {$[95 \%$ con } & \\
\hline audit & .1867982 & .0797242 & 2.34 & 0.025 & .0252616 & .3483348 \\
\hline rel_size & .3547538 & .1526599 & 2.32 & 0.026 & .0454355 & .6640721 \\
\hline _cons & .3995629 & .077173 & 5.18 & 0.000 & .2431956 & .5559302 \\
\hline Number of observations & 40 & & & & & \\
\hline F statistics & 5.42 & & & & & \\
\hline$P$ value & 0.0086 & & & & & \\
\hline $\mathrm{R}$ squared & 0.2266 & & & & & \\
\hline Adjusted R squared & 0.1848 & & & & & \\
\hline
\end{tabular}

The resulting model is significant ( $\mathrm{F}$ statistics $=0.0086$ ), therefore, if rejecting the null hypothesis that all covariates have coefficients equal to zero. The final model shows as statistically significant variables the audit firm size, the relative company size, and the intercept, at the confidence interval of $95 \%$. Based on multicollinearity test by using the variation inflation factor (VIF) test, it was found that the VIFs found are below 3 According to Gujarati (2006), multicollinearity problems are considered when VIF above 10 are observed. Therefore, in the final model, based on the VIF test, there are no multicollinearity problems among the explanatory variables.
The model has indicated a heteroscedasticity problem of waste in the Breush-Pagan/Cook-Weisberg test. However, according to Wooldridge (2006), heterocedasticity does not cause bias or inconsistency in the regression coefficients or in $\mathrm{R}^{2}$, revealing problems only in $t$ statistics. Wooldridge (2006) suggests as a corrective procedure for this problem using a robust $t$ statistics concerning heteroscedasticity. Running up a robust regression in Stata, with only the audit explanatory variables and relative size, we obtained the results displayed in Table 5.

Table 5 Results of robust regression

\begin{tabular}{|c|c|c|c|c|c|c|}
\hline & Coef. & Std. Err & $\mathbf{t}$ & $P>|t|$ & [95\% con & \\
\hline audit & .1867982 & .0536262 & 3.48 & 0.001 & .0781413 & .2954551 \\
\hline rel_size & .3547538 & .1171841 & 3.03 & 0.004 & .1173163 & .5921913 \\
\hline _cons & .3995629 & .0478862 & 8.34 & 0.000 & .3025362 & .4965896 \\
\hline Number of observations & 40 & & & & & \\
\hline F statistics & 13.08 & & & & & \\
\hline$P$ value & 0.0001 & & & & & \\
\hline R squared & 0.2266 & & & & & \\
\hline
\end{tabular}

In fact it is observed that the model remains statistically significant with no change in its explanatory power. The co- efficient values were not changed, only on the $t$ statistics for each regressor.

\section{CONCLUSIONS}

This paper sought to analyze the level of disclosure of information on business combinations and the factors that influenced on the company's decision to disclose information on these transactions, in the year that CPC 15 entered into force.
To test the hypotheses, independent variables cited in the meta-analysis by Ahmed and Courtis (1999) and control variables reported in the literature were used. It is noticed that the disclosure index was low. This may be attributed to the fact that 2010 was the first year of 
the Accounting Standard CPC 15 - and, thus, preparers and auditors were not, yet, well prepared to apply the standard.

Regarding the acquiring company's size, it was not concluded that larger companies disclose more information on business combinations, a result that is different from that found in most international surveys on disclosure, but in line with what was found by Glaum and Street (2003), Street and Bryant (2000), and Street and Gray (2002). It is emphasized that this study refers to a specific dimension of disclosure related to information on business combinations, therefore, with different characteristics when compared to other studies cited on disclosure. Nevertheless, this is information disclosure and, thus, we compared the results to other surveys regarding disclosure.

On the other hand, corroborating what was observed in the analysis of the correlation between variables, it was confirmed that the control variable relative size showed statistical significance with a positive coefficient, as observed by Málaga (2007), indicating that acquiring firms are concerned about disclosing more information on business combinations the higher the value of the transaction in relation to the total of their own assets, i.e. when investment is significant. This seems to be due to the concern of acquiring companies with the influence of the acquired company on its results.

The variable recognized goodwill in relation to transferred consideration value had no statistical significant, unlike what was found by Shalev (2007). A possible explanation for the rejection of this hypothesis is that the calculation of goodwill is usually done with a high dose of arbitrariness or even influenced by tax legislation. We can also notice that, in a large part of transactions, goodwill was computed as the difference between the amount paid and its book value and this difference was entirely justified as expected future profitability.

The hypothesis that firms with greater capital dispersion disclose more information on business combinations was not confirmed, contrary to what was reported by Leuz and Verrecchia (2000) and Raffournier (1995). A hypothesis for the result is that even with capital dispersion, shareholder agreements ensure control of these companies by a controller or a control group, according to a study conducted by Gorga (2008), and, in the presence of control concentration, disclosure would not be required.

The results indicate that audit firm size influences on the level of disclosure of information on business combination, as observed by Ahmad et al. (2003). Large international audit companies, familiar with the requirements of IFRS 3 at the international level, apply this knowledge to Brazil, influencing on the disclosure of information on a business combination undertaken by audited companies.

Finally, we did not confirm the hypothesis that the level of disclosure on business combinations is influenced by acquiring company's participation in ADR programs. Murcia and Santos (2009) found different results. A justification for the different result is that the companies used for analysis were different. Murcia and Santos (2009) used the 100 largest companies listed on BOVESPA, which published financial statements for the fiscal year 2007 and this study analyzed all companies having shares traded on the BM\&FBOVESPA in 2010 that reported to acquired the stock control of other companies. Furthermore, the metrics used by Murcia and Santos (2009) to calculate the disclosure level was based on voluntarily disclosed information, whereas this study used the compulsory disclosure items defined by CPC 15. Therefore, although both analyze the influence of issuing ADRs on disclosure, they are not similar surveys.

The results obtained by this survey provide a contribution to the studies that have been recently conducted in Brazil, related to the evaluation of the accounting information disclosure levels after the adoption of IFRS and CPCs. Furthermore, it provides evidence for the specific analysis of companies that undertook business combinations. These transactions, as discussed in the introduction, moved large volumes of resources and users of accounting information are directly affected by the outcomes of such transactions. It also contributes to international studies related to accounting information disclosure, insofar as it provides empirical evidence on impacts deriving from the adoption of IFRS in Brazil. The findings also contribute to the literature in the field by providing new evidence on the phenomenon of disclosure, studied both internationally and in Brazil and from a very specific perspective, the disclosure of information on business combinations.

Thus, in terms of practical consequences for such users, through the positive relation obtained between the information disclosure level and the audit firm size, it is expected that companies audited by the Big Four provide a rather transparent information to the market. On the other hand, the positive relation between the disclosure level and the acquiring company's relative size draws attention to the aspect of transaction relevance.

Another aspect that draws attention refers to the low disclosure level itself (and consistent with other studies addressing mandatory disclosure), since the index was obtained by checking information disclosure on business combinations considered as compulsory. Although recognizing that the level of disclosure of such information has not been high due to the fact that this legislation constitutes a novelty, if there is not an active role on the part of regulators, we are at risk of do not move forward to improve the information disclose level, since a standard without enforcement may be understood only as a suggestion. The results and conclusions of this study had some limitations. The first is that the disclosure of information on business combinations was limited to the fiscal year 2010, which was the onset of the application of CPC 15. As they were the early financial statements where compliance with the requirements of CPC 15 were compulsory, it is reasonable to assume that errors might be found in the financial statements. It is believed that surveys addressing a broader period of stability 
and the standards' estability could provide the disclosure level with robustness and knowledge on the evolution. This could help regulators to evaluate the need for enforcement. On the other hand, this does not invalidate this survey, because it portrays the situation observed when CPC 15 entered into force. Another analysis that could be suggested might be a comparison between the situation before and after CPC 15 . However, taking into account that the requirement to disclose this kind of information prior to the adoption of CPC 15 was much lower, so, such a comparison could not be feasible.

The second limitation is related to the construction of the disclosure index INDCOMB. Although such a cons- truction has been based on Shalev (2009) and on the requirements of CPC 15, this involves the creation of a not directly observable construct. In addition, there is the fact that, in the content analysis of financial statements to prepare the disclosure index INDCOMB, the researcher used a considerable amount of opinion. Finally, it is worth highlighting the limitations of the econometric model employed, since it is restricted to a few independent variables that the researcher considered as relevant to explain the level of disclosure of information on business combination. The choice of variables was based on previous studies and on the need to construct proxies to analyze the hypotheses.

\section{References}

Ahmad, Z., Hassan S., \& Mohammad, J. (2003). Determinants of environmental reporting in Malaysia. International Journal of Business Studies, 11, 69-90.

Ahmed, K., \& Courtis, J. K. (1999). Associations between corporarte characteristics and disclosure levels in annual reports: a meta-analysis. British Accounting Review, 31, 35-61.

Archambault, J. J., \& Archambault, M. E. (2003). A multinational test of determinants of corporate disclosure. International Journal of Accounting, 38, 173-194.

Ayers, B. C., Schwab, C. M., \& Utke, S. (no prelo). Noncompliance with mandatory disclosure requirements: the magnitude and determinants of undisclosed permanently reinvested earnings. The Accounting Review.

Botosan, C. A. (1997). Disclosure level and the cost of equity capital. The Accounting Review, 72(3), 323-349.

Camargos, M. A., \& Barbosa, F. V. (2003). Fusões, aquisições e takeovers: um levantamento teórico dos motivos, hipóteses testáveis e evidências empíricas. Caderno de Pesquisa em Administração, 10(2), 17-38.

Camargos, M. A., \& Coutinho, E. S. A. (2008). Teoria da firma e a fundamentação teórica para fusões e aquisições: uma análise de suas. interfaces. RAC-Eletrônica, 2(2), 273-295.

Chatham, M. D. (2008). Assessing the extent of compliance with international accounting standards. Journal of International Business Research, 7(1), 61-90.

Cooke, T. E. (1989). Disclosure in the corporate annual reports of swedish companies. Accounting and Business Research, 19(74), 113-124.

Costa Jr., J. V. (2003). Uma avaliação do nível de evidenciação das companhias abertas, no Brasil, no tocante aos instrumentos financeiros. Revista Contabilidade e Finanças, 14(32), 23-39.

Deangelo, L. E. (1981). Auditor size and audit quality. Journal of Accounting and Economics. 3, 183-199.

Devalle, A., \& Rizzato, F. (2012). The quality of mandatory disclosure: the impairment of goodwill. An empirical analysis of european listed companies. Procedia Economics and Finance, 2, 101-108.

Dumontier, P., \& Raffournier, B. (1998). Why firms comply voluntarily with IAS: an empirical analysis with Swiss data. Journal of International Financial Management and Accounting. 9(3), 216-245.

Dye, R. A. (2001). An evaluation of "essays on disclosure" and the disclosure literature in accounting. Jounal of Accountung an. Economics, 32, 181-235.

Glaum, M., \& Street, D. L. (2003). Compliance with the disclosure requirements of Germany's new market: IAS versus US GAAP. Journal of International Financial Management and Accounting. 14, 64-100.

Gorga, E. (2008). Changing the paradigm of stock ownership from concentrated towards dispersed ownership? Evidence from Brazil and consequences for emerging countries (working paper). Recuperado em $1^{\circ}$ de março de 2001, de http://scholarship.law.cornell.edu/clsops_papers/42
Gujarati, D. N. (2006). Econometria Básica (4a ed.). Rio de Janeiro: Elsevier.

Healy, P. M., \& Palepu, K. G (2001). Information asymmetry, corporate disclosure, and the capital markets: a review of empirical disclosure literature. Journal of Accounting and Economics, 31, 405-440.

Hodgdon, C., Tondkar, R. H., Harless, D. W., \& Adhikari, A. (2008). Compliance with IFRS disclosure requirements and individual analysts' forecast errors. Journal of International Accounting and Taxation, 17, 1-13.

Kent, P., \& Stewart, J. (2008). Corporate governance and disclosures on the transition to international financial reporting standards. Accounting and Finance, 48, 649-671.

Lanzana, A. P. (2004). Relação entre disclosure e governança corporativa das empresas brasileiras. Dissertação de Mestrado, Faculdade de Economia, Administração e Contabilidade, Universidade de São Paulo, São Paulo.

Leftwich, R. (1980). Market failure fallacies and accounting information. Journal of Accounting and Economics, 2, 193-211.

Leuz, C., \& Verrecchia, R. (2000). The economic consequences of increased disclosure. Journal of Accounting Research, 38, 91-124.

Leuz, C., \& Wysocki, P. (2008). Economic consequences of financial reporting and disclosure regulation: a review and suggestions for future research (working paper). Recuperado em $1^{\circ}$ de março de 2011, de http://ssrn.com/abstract $=1105398$

Lima, G. A. S. F. (2009). Nível de evidenciação $\times$ custo da dívida das empresas brasileiras. Revista Contabilidade e Finanças, 20(49), 95-108.

Lopes, A. B., \& Rodrigues, L. L. (2007): Accounting for financial instruments: an analysis of the determinants of disclosure in the Portuguese stock exchange. The Journal of Accounting, 42(1), 25-56.

Malacrida, M. J. C., \& Yamamoto, M. M. (2006). Governança corporativa: nível de evidenciação das informações e sua relação com a volatilidade das ações do Ibovespa. Revista Contabilidade e Finanças, 17, 65-79.

Málaga, F. K. (2007). Estudo do risco sistêmico das empresas resultantes de fusões e aquisições e às expectativas dos investidores e dos gestores. Tese de Doutorado, Faculdade de Economia, Administração e Contabilidade, Universidade de São Paulo, São Paulo.

Malaquias, R. F., Lemes, S., Carvalho, L. F., \& Tavares, M. (2012). Disclosure of financial instruments.and capital cost of Brazilian companies. Asian Journal of Business and Management Sciences, 1(9), 16-27.

Mapurunga, P. V. R., Ponte, V. M. R., Coelho, A. C. D., \& Meneses, A. F. (2011). Determinantes do nível de disclosure de instrumentos financeiros derivativos em firmas brasileiras. Revista Contabilidade \& Finanças, 22(57), 263-278.

Marston, C. L., \& Shrives, P. J. (1991). The use of disclosure indices in accounting research: a review article. Britsh Accounting Review, 25, 195-210. 
Martins, E., \& Iudicibus, S. (2011). Intangível: sua relação contabilidade/direito - teoria, estruturas conceituais e normas - problemas fiscais de hoje. In A. B. Lopes, \& R. Q. Mosquera (Coord), Controvérsias jurídico-contábeis (aproximações e distanciamentos) (Vol. 2). São Paulo: Dialética.

Murcia, F. D., \& Santos, A: (2009). Fatores determinantes do nível de disclosure voluntário das companhias abertas no Brasil. Revista de Educação e Pesquisa em Contabilidade, 3(2), 72-95.

Raffournier, B. (1995). The determinants of voluntary disclosure by Swiss listed companies. European Accounting Review, 4, 261-280.

Robinson, J. R., Xue, Y., \& Yu, Y. (2011). Determinants of disclosure noncompliance and the effect of the SEC review: evidence from the 2006 mandated compensation disclosure regulations. The Accounting Review, 86(4), 1415-1444.

Salotti, B. M., \& Yamamoto, M. M. (2008). Divulgação voluntária da demonstração dos fluxos de caixa no mercado de capitais brasileiro. Revista Contabilidade e Finanças, 19(48), 37-49.

Schipper, K. (2007). Required disclosures in financial reports. The Accounting Review, 82(2), 301-326.

Shalev, R. (2007). Managerial discretion in business combinations reporting under SFAS 141. Tese de doutorado, Graduate School of Arts and Science, Columbia University, Ann Arbor, Ml.

Shalev, R. (2009). The information content of business combination disclosure level. The Accounting Review, 84(1), 239-270.

Shleiffer, A., \& Vishny, R. (1986). Large shareholders and corporate control. Journal of Political Economy, 94, 461-488.
Singhvi, S. S., \& Desai, H. B. (1971). An empirical analysis of the quality of corporate financial disclosure. The Accounting Review, 46, 120-138.

Street, D. L., \& Bryant, S. M. (2000). Disclosure level and compliance with * IASs: a comparison of companies with and without US listings and fillings. International Journal of Accounting, 35(3), 305-329.

Street, D. L., \& Gray, S. J. (2002). Factors influencing the extent of corporate compliance with International Accounting Standards: summary of a research monograph. Journal of International Accounting, Auditing \& Taxation, 11, 51-76.

Tsalavoutas, I., Evans, L.; \& Smith, M. (2010). Comparison of two methods for measuring compliance with IFRS mandatory disclosure requirements. Journal of Applied Accounting Research, 11(3), 213-228.

Verrecchia, R. (2001). Essays on disclosure. Journal of Accounting and Economics, 32, 97-180.

Wallace, R. S. O., \& Naser, K. (1995). Firm-specific determinants of the comprehensiveness of mandatory disclosure in the corporate annual reports of firms listed on the stock exchange of Hong Kong. Journal of Accounting and Public Policy, 13, 311-368.

Wiseman, J. (1982). An evaluation of environmental disclosures made in corporate annual reports. Accounting Organization and Society, 7(1), 53-63.

Wooldridge, J. M. (2006). Introdução à econometria: uma abordagem moderna. São Paulo: Pioneira Thomson Learnig.

Yeoh, J. (2005). Compliance with mandatory disclosure requirements by New Zealand listed companies. Advances in International Accounting, $18,245-262$. 